\title{
ACUTE DISORDERS OF METABOLISM OF CARDIOMYOCYTE IN CARDIAC CONTUSION
}

\section{V.P. Novoselov, S. V. Savchenko, A.N. Porvin, D.A. Koshlyak}

Abstract. New data on ultrastructural changes in cardiomyocytes in cardiac contusion in an experiment are submitted. The authors have identified the development of acute myocardial contractile failure that is associated with a statistically significant decrease in the content of ribosomes and glycogen in cardiomyocytes involved in the plastic and energy metabolism of the myocardium.

Key words: morphology, diagnosis, heart damage, cardiac contusion.

State Medical University (Novosibirsk, Russia)

Рецензент - проф. В.Т. Бачинський

Buk. Med. Herald. - 2013. - Vol. 17, № 3 (67), part 1. - P. 113-116

Надійшла до редакції 05.06.2013 року

(C) В.П. Новоселов, С.В. Савченко, А.Н. Порвин, Д.А. Кошляк, 2013

УДК 340.6:616.711.1-001.5-079.5]-053.88

В.О. Ольховський, О.М. Пешенко

\section{ПОКАЗНИКИ КОМП'ЮТЕРНОЇ СТАБІЛОГРАФІЇ ПРИ СУДОВО-МЕДИЧНІЙ ЕКСПЕРТИЗІ ТРАВМ ШИЙНОГО ВІДДІЛУ ХРЕБТА ТА НАВКОЛОХРЕБЦЕВИХ СТРУКТУР}

Харківський національний медичний університет MO3 України

\begin{abstract}
Резюме. Ушкодження шийного відділу хребта (ШВХ) та відповідних навколохребцевих морфологічних структур здатні суттєво впливати на стан функції підтримання вертикального положення тіла за рахунок формування розладів опорно-рухового апарата (OРA), зокрема хребта - основної системи кінематичного ланцюга ОРА. Оскільки при тілесних ушкодженнях ШВХ
\end{abstract}

Вступ. Найбільш важливою при тілесних ушкодженнях ШВХ є оцінка статолокомоторних функцій нервово-м'язової системи. Стан цих функцій можна розглядати як інтегративний показник управління площею опори і збереження вертикальної стійкості тіла за рахунок нервовом'язового апарата. Сукупність усіх складових, що впливають на коливання загального центра мас (ЗЦМ), утворюють складну біомеханічну структуру статики руху.

Підтримання рівноваги при ушкодженнях ШВХ залежить від надійності функціонування механізмів регуляції пози. Зокрема, при неускладнених ушкодженнях ШВХ та паравертебральних структур, включення компенсаторних та пристосувальних процесів має "прихований характер", тоді як систематичне перенапруження, насамперед паравертебральних структур, негативно впливає на стан нервово-м'язової та судинної систем, поступово формуючи неврологічні вертеброгенні симптоми. У межах цієї проблеми недостатньо вивченим $є$ такий значимий фактор, як формування поєднананих сенсорних та моторних асиметрій.

Мета дослідження. Вивчити інформативні показники комп'ютерної стабілографії для судово-медичної оцінки ступеня тяжкості тілесних процеси компенсації хребтоворухомого сегмента (ХРC) порушуються, то і визначення інформативних біомеханічних індикаторів - $\epsilon$ актуальним для судово-медичної практики.

Ключові слова: травма шийного відділу хребта, комп'ютерна стабілографія.

ушкоджень шийного відділу та відповідних навколохребцевих структур.

Матеріал і методи. Комплекс стабілографічних методик виконано на приладі - статографі, до складу якого входять комп'ютер із відповідним програмним забезпеченням та спеціальна біомеханічна платформа [1]. У процесі дослідження вивчено стан функції підтримання вертикального положення методом комп'терної стабілографії у 82 осіб із тілесними ушкодженнями ШВХ та навколохребцевих структур.

Результати дослідження та їх обговорення. При тяжкому ступені тяжкості тілесних ушкоджень (ТСТТУ) ШВХ та відповідних навколохребцевих структур виявлена значна $(\mathrm{p} \leq 0,001)$ асиметрія положення проекції ЗЦМ до початку руху (проявлялася зміщенням ЗЦМ у фронтальній пло-

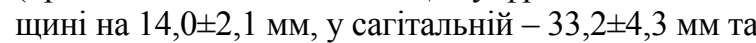
менш виразна асиметрія при переході від статичного вертикального положення до динаміки (ходіння); співвідношення висоти підйому траєкторії складало в середньому $0,74 \pm 0,07$ од. У цей період відбувається функціональна перебудова OPА, що проявляється в переміщенні ЗЦМ між опорною та маховою кінцівками.

При середньому ступені тяжкості тілесних ушкоджень (ССТТУ) ШВХ та відповідних навко-

(C) В.О. Ольховський, О.М. Пешенко, 2013 
лохребцевих структур виявлено асиметрію статолокомоторного процесу при первинно (до початку руху) більш симетричному розташуванні ЗЦМ. Так, при статичному вертикальному положенні тіла зміщення проекції ЗЦМ на площі опори у фронтальній площині склало 12,6士3,1 мм, тоді як у сагітальній - переміщення проекції ЗЦМ було достовірно $(\mathrm{p} \leq 0,05)$ вищим та склало $21,0 \pm 4,2$ мм. Водночас зазначимо, що коефіцієнт відношення висоти траєкторії зростання показника переміщення ЗЦМ $\left(\mathrm{h}_{1}\right)$ при переході від статики (стояння) до динаміки (ходьба) складає $0,88 \pm 0,11$ та не відрізняється ( $\geq 0,05)$ від осіб із легким та тяжким ступенем тілесних ушкоджень ШВХ (відповідні коефіцієнти становлять $0,78 \pm 0,09$ та $0,90 \pm 0,06)$. Коефіціент статолокомоторної просторової адаптації для різних сторін також демонструє тенденцію до асиметрії та в цілому він дещо менш виразний, ніж при ТСТТУ (тяжкий ступінь - 0,74 $\pm 0,07$, середньої тяжкості - $0,86 \pm 0,08, \mathrm{p} \geq 0,05)$.

При легкому ступені тяжкості тілесних ушкоджень (ЛСТТУ) ШВХ та відповідних навколохребцевих структур виявлено дещо більше зміщення ЗЦМ у сагітальній, ніж у фронтальній пло-

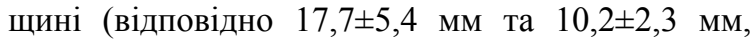
$\mathrm{p} \geq 0,05)$; при цьому зміщення ЗЦМ у сагітальній площині було достовірно $(\mathrm{p} \leq 0,05)$ меншим, ніж при ТСТТУ. Коефіцієнт відношення висоти траєкторії зростання показника переміщення ЗЦМ при переході від статики до динаміки складає
$0,90 \pm 0,06$ та не відрізняється $(\mathrm{p} \geq 0,05)$ від осіб 3 середнім та ТСТТУ ШВХ. Коефіцієнт статолокомоторної просторової адаптації для різних сторін - симетричний та на боці ушкодження достовірно відрізнявся від аналогічного показника групи осіб із ТСТТУ ШВХ.

\section{Висновок}

Таким чином, метод комп'ютерної стабілографії дозволить об'єктивізувати висновки експерта, їх точність та достовірність для судовомедичної оцінки ступеня тяжкості тілесних ушкоджень шийного відділу та відповідних навколохребцевих структур.

Перспективи подальших досліджень судово-медичного значення статолокомоторних порушень у осіб із тілесними ушкодженнями ШВХ пов'язані в систематизації відомих методів неінвазивної діагностики (насамперед, реоенцефалографії, транскраніальної допплерометрії) із впровадженням їх у алгоритми судово-медичних досліджень ступеня тяжкості тілесних ушкоджень.

\section{Література}

1. Автоматизированная компьютерная стабилографическая диагностика атаксий с использованием анализа векторов и статистического метода «деревьев классификации» / В.И. Усачев, Х.Т. Абдулкеримов, С.Г. Григорьев [и др.]; Воен.-мед. академия (СПб); Уральская гос. мед. академия (Екатеринбург); ЗАО «ОКБ “Ритм"» (Таганрог). - СПб., 2003. - 24 с.

\section{ПОКАЗАТЕЛИ КОМПЬЮТЕРНОЙ СТАБИЛОГРАФИИ ПРИ СУДЕБНО-МЕДИЦИНСКОЙ ЭКСПЕРТИЗЕ ТРАВМ ШЕЙНОГО ОТДЕЛА ПОЗВОНОЧНИКА И ОКОЛОПОЗВОНКОВЫХ СТРУКТУР}

\section{В.О. Ольховский, О.М. Пешенко}

Резюме. Повреждение шейного отдела позвоночника (ШОП) и соответствующих околопозвонковых морфологических структур способны существенно влиять на состояние функции поддержания вертикального положения тела за счет формирования расстройств опорно-двигательного аппарата (ОДА), в частности позвоночника - основной системы кинематической цепи ОДА. Поскольку при телесных повреждениях ШОП процессы компенсации позвоночно-двигательного сегмента (ПДС) нарушаются, то и определение информативных биомеханических индикаторов - актуально для судебно-медицинской практики.

Ключевые слова: травма шейного отдела позвоночника, компьютерная стабилография.

\section{INDICATORS FOR COMPUTER STABILOGRAPHY IN CASE OF A FORENSIC MEDICAL EXAMINATION OF INJURIES OF THE CERVICAL PORTION OF THE SPINE AND THE PERIVERTEBRAL STRUCTURES}

\section{V.O. Olkhovskyi, O.M. Peshenko}

Abstract. Damage to the cervical portion of the spine (CPS) and the corresponding perivertebral morphological structures can significantly affect the status of the function of maintaining the vertical position of the body through the formation of disorders of the musculoskeletal system (MSS), in particular the spine - the basic system of the kinematic chain of the MSS. Since, in case of SPS injuries the processes of compensation of the spinal motion segment (SMS) are violated, an identification of informative biomechanical indicators - is topical for forensic-medical practice.

Key words: cervical spine injury, computer stabilography.

National Medical University of Ukraine’s MHP (Kharkiv)

Рецензент - проф. В.Т. Бачинський

Buk. Med. Herald. - 2013. - Vol. 17, № 3 (67), part 1. - P. 116-117

Надійшла до редакції 08.06.2013 року

(C) В.О. Ольховський, О.М. Пешенко, 2013 